\title{
The Analysis of Heat Storage Capacity and the Formation Characteristics of Geothermal Resources in Sedimentary Basins — A Case Study on Dunhuang Basin
}

\author{
Yujiang He, Guiling Wang, Wenjing Lin and Wei Zhang* \\ Institute of Hydrogeology and Environmental Geology, Shijiazhuang 050061, China
}

\begin{abstract}
The geothermal resources in sedimentary basin are affected by many factors because the characteristic of geothermal reservoirs is very complex, so the heat storage capacities are hard to calculate. This paper took Dunhuang Basin as an example to analyze the geological structure, stratigraphic structure and the formation mechanism of geothermal water based on the formation characteristics of the geothermal resources. The analysis results showed the geothermal reservoir parameters, including the area, thickness, and temperature of the geothermal reservoir, and porosity, etc. Based on geothermal reservoir model, the conclusion was that the geothermal resource of Dunhuang Basin was $7.75 \mathrm{E}+16 \mathrm{~kJ}$. The results provided an advice for the exploitation of geothermal resources in sedimentary basins.
\end{abstract}

Keywords: Heat storage, geothermal reservoir characteristic, geothermal reservoir model, sedimentary basin.

\section{INTRODUCTION}

The formation of geothermal resources in sedimentary basins is closely related to the formation lithology [1]. For example, in the large basin, illuvial horizon is thick. And the storage layer has high porosity and permeability which formed large numbers of coarse fragments and interlays composed of lots of fine particles [2]. The interlays have a function of accumulating heat and thermal insulation for the storage layer. So this kind of basin has great capacity to store heat.

The hydrogeological condition also has greatly influenced the formation of geothermal resources in sedimentary basins. The large basins which have sufficient scale, make the hydrodynamic condition show a clear zonation. The outer zone shows a positive runoff, and the inner zone shows sluggish runoff. The groundwater goes through the outer zone and then enters the inner zone in which the groundwater runs horizontally [3]. The groundwater fully absorbs the heat from the rock and achieves the same temperature as the rock. The formation of geothermal resources in sedimentary basins is closely related with the basal structure, magmation and tectonic activities.

Lots of factors have affected the geothermal resources in sedimentary basins making the characteristics of geothermal reservoirs very complex and the heat storage capacity hard to calculate. Therefore, quantitative interpretation of geothermal data (geothermal simulation) is a powerful tool for understanding the structure of the lithosphere in various geodynamic settings [4].

*Address correspondence to this author at the Institute of Hydrogeology and Environmental Geology, Zhonghua Street 268 Code, Shijiazhuang, Postcard: 050061, China; Tel: 86-031167598537;

E-mail: heyujiang86@163.com
Studies of the physical and chemical characteristics [5-8] and geographic distribution of thermal springs with respect to geologic structures form an important part in the initial stages of geothermal exploration. Site-specific information about the lithological characteristics of subsurface layers and the thermal fields is used for the assessment of geothermal resources associated with thermal springs. Nevertheless, mostly such procedures ignore the existence of eventual disturbing effects of large-scale movements of groundwater on the occurrence of thermal fluids [9].

It is necessary to analyze the geological structure, stratigraphy structural characteristics and the formation mechanism of geothermal water based on the formation characteristics of the geothermal resources and then establish the conceptual model of the geothermal field. Taking Dunhuang Basin for example, the established model uses the selected parameters and finally calculates the quantity of geothermal reservoir resources of sedimentary basin.

\section{THE FORMATION CHARACTERISTICS OF GEOTHERMAL RESOURCES IN DUNHUANG BASIN}

Dunhuang Basin with the area of $3 \times 10^{4} \mathrm{~km}^{2}$ is located in the western end of the Hexi Corridor, between Sanwei Mountain and the north mountain of the Hexi Corridor. Sanwei Mountain is between the Dunhuang Basin and Akesai Basin.

Dunhuang Basin is in the north of Aerjin fault. It is the junction between Tarim block and Alashan block and also between Qilian orogenic belt and north mountain orogenic belt. Dunhuang Basin is the marginal basin which is formed by the Tarim block extending eastward and is developed in the Lower-Middle Jurassic, Lower Cretaceous, Neogene and Quaternary strata based on the Archean-Lower Proterozoic Dunhuang group. 


\section{East-west section}

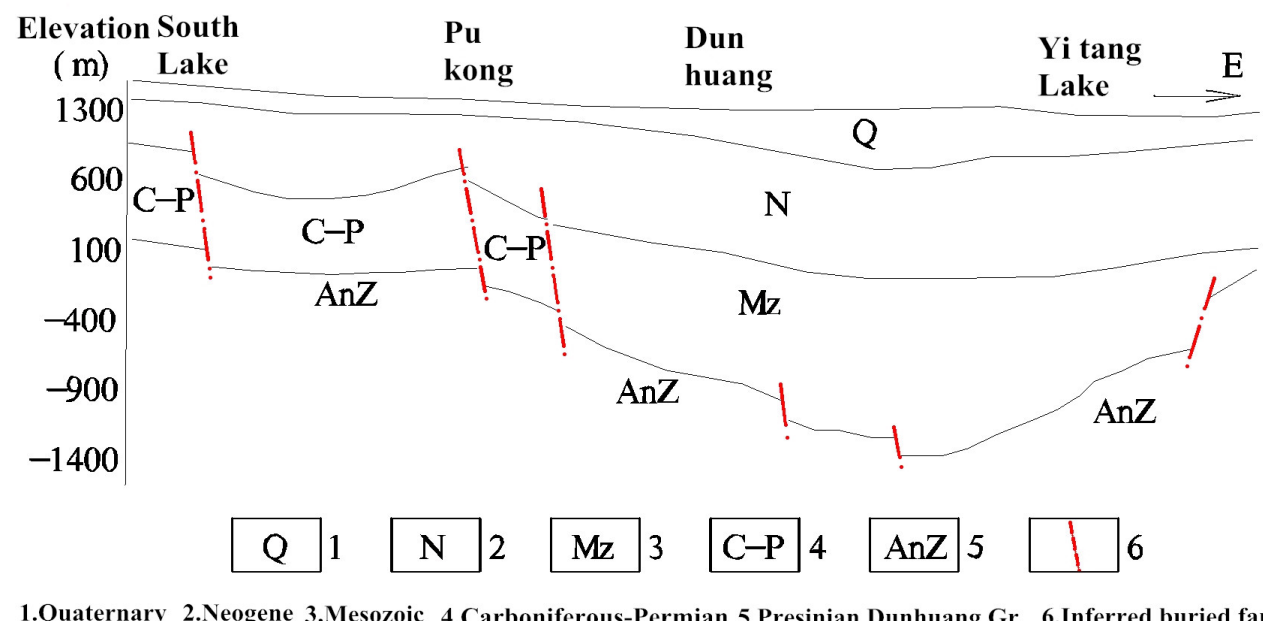

Fig. (1). The geological section inferred from seismic data in Dunhuang Basin.

Wudun-Yitang Lake fault in Dunhuang Basin has the optimum prospect of geothermal resource. According to the seismic data, the fault depression is widely slow and the sedimentation center is in the south. The thickness of the basement is about $3000 \mathrm{~m}$. The ground outcrops show that the main strata is the Jurassic, whose thickness is about 2200 $\mathrm{m}$ and the area is $2076 \mathrm{~km}^{2}$. The thickness of the lower and middle Jurassic is about $1000 \mathrm{~m}$ and the area is nearly 1000 $\mathrm{km}^{2}$. The buried depth of the top of the lower and middle Jurassic is more than $2000 \mathrm{~m}$ (Fig. 1).

The temperature of the abnormal geothermal wells in the basin and in the surrounding area is between $16.5-19^{\circ} \mathrm{C}$. In the above-mentioned Mesozoic-Cenozoic sedimentary layers, the thermal insulation coating of the basin geothermal field is composed of mudstone, sandy mudstone, muddy sandstone of Quaternary, Neogene and late Jurassic $\left(\mathrm{J}_{3}\right)$. The thermal reservoir is composed of the gravelly sandstone, sandstone of middle-lower Jurassic $\left(\mathrm{J}_{1-2}\right)$.

From the above mentioned facts, it seems that the geothermal distribution, geothermal evolution, the thermal structure and deep lithospheric thermal conditions of different types of sedimentary basins have significant differences.

The geothermal evolution genetic models of the rift basin, the depression basin, compressive orogenic type basin and the sedimentary basin have been analyzed. The geothermal activity of the rift basin decreased with the evolution of geological history. During the tension-rift stage, the heat flow value is high. But the recent heat flow value depends on the time when the rift valley occurred. The Mesozoic-Cenozoic rifts had high heat flow values and had the typical structure of "hot crust-hot mantle". However, the ancient rift has low heat flow values. The stable depression basin was characterized by a low heat value, which depends on the geological conditions of the basin. The compressive orogenic type basin has poor geothermal condition, that's because of the small heat flow from the deep level.

Based on the analysis of the geological structure, stratigraphy structure and the formation mechanism of the geothermal water, it is concluded that the Dunhuang Basin has a good condition of geothermal field. The conceptual model of geothermal field is shown in Fig. (2).

\section{THE CALCULATING ANALYSIS OF HEAT STORAGE}

\subsection{The Determination of the Calculated Parameters}

\subsubsection{The Area of the Geothermal Reservoir}

The effective area is delineated where the wells with the depth are less than $4000 \mathrm{~m}$ and the temperature of wellhead is higher than $40^{\circ} \mathrm{C}$, and the water flow of single well is more than $20 \mathrm{~m}^{3} / \mathrm{h}$. Then the boundary of geothermal district, the geothermal field, the contours of the geothermal reservoir temperature and the geothermal reservoir thickness should be digitized by the computer and calculated.

\subsubsection{The Thickness of the Geothermal Reservoir}

The thickness of the geothermal reservoir equals to the stratigraphic thickness multiplied by the sand thickness ratio. The geothermal reservoir thickness of bedrock equals to the evaluated average thickness of bedrock, less than $4000 \mathrm{~m}$, multiplied by the reservoir thickness ratio. The sand thickness ratio of the geothermal reservoir is determined by the statistical results of the drillings in the geothermal field, and the bedrock reservoir thickness ratio references to the regional value.

\subsubsection{The Temperature of the Geothermal Reservoir}

The temperature of the geothermal reservoir is estimated by earth temperature gradient. The calculation formula of the geothermal reservoir temperature is shown as follows:

$$
T_{Z}=T_{0}+\frac{\Delta T}{100}\left(H-H_{0}\right)
$$

$\mathrm{T}_{\mathrm{Z}}$ The temperature of the roof geothermal reservoir, ${ }^{\circ} \mathrm{C}$.

$\mathrm{T}_{0}$-The temperature of the constant temperature zone or annual mean temperature, ${ }^{\circ} \mathrm{C}$ 


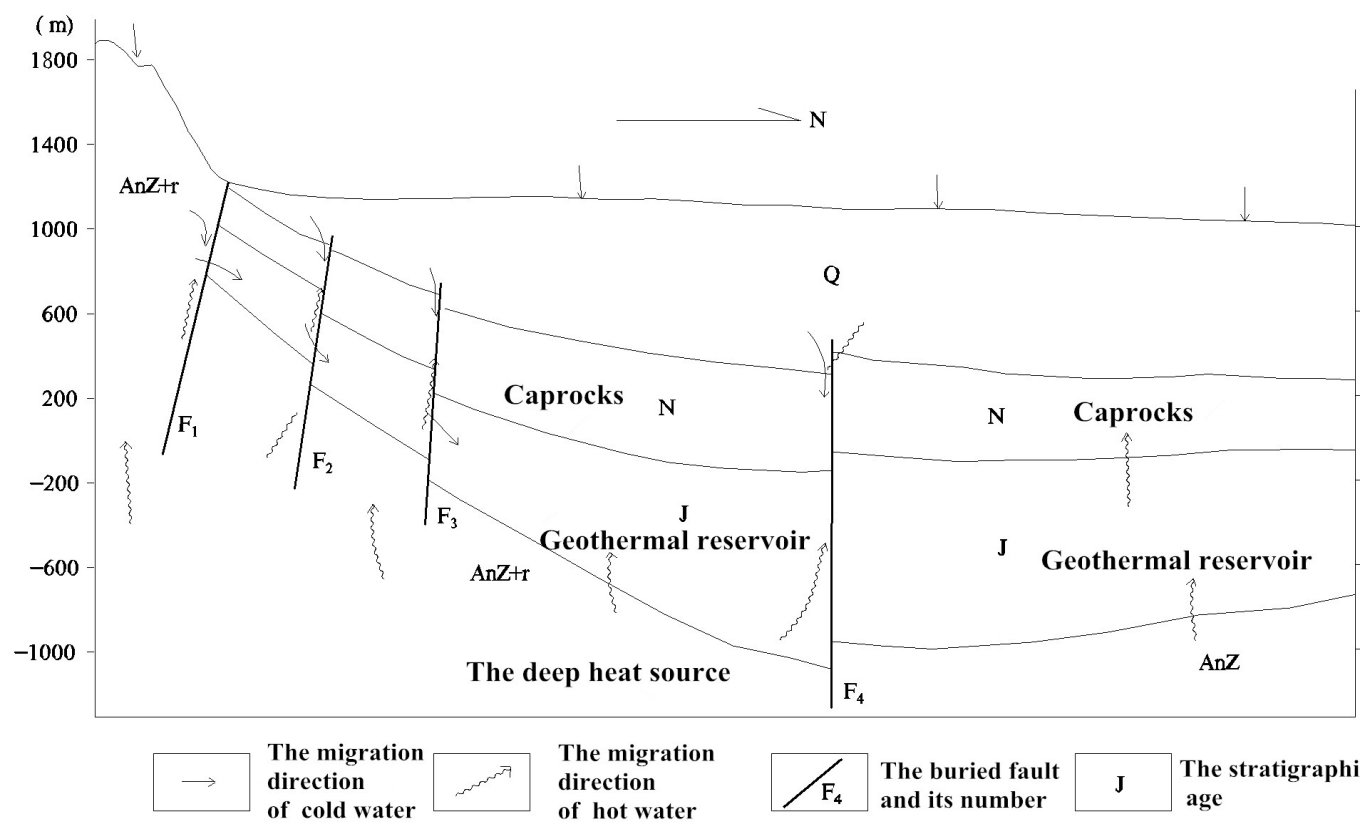

Fig. (2). The conceptual model of geothermal field in Sedimentary Basin.

$\Delta \mathrm{T}$ - The earth temperature gradient., ${ }^{\circ} \mathrm{C} / 100 \mathrm{~m}$.

$\mathrm{H}_{0^{-}}$The depth of the constant temperature zone, $\mathrm{m}$.

$\mathrm{H}$ - The depth of the roof geothermal reservoir, $\mathrm{m}$.

\subsubsection{The Porosity}

The porosity is determined by the measurement information of the drillings when the geothermal field has borehole data or equals to the local regional empirical value in the literature when there are no borehole information.

\subsubsection{The Hydrogeological Parameters}

The hydrogeological parameters would be taken according to the existing pumping tests, or referring to Hydrogeological Handbook and local empirical value in the related reports when there is no pumping test information.

\subsection{Calculation of the Geothermal Storage}

The thermal reservoir method is applied to compute the geothermal storage and the expression is as follows [10]:

$Q=C_{r} \rho_{r}(1-\varphi) V\left(T_{1}-T_{0}\right)+C_{w} \rho_{w} q_{w}\left(T_{1}-T_{0}\right)$
Q- The amount of geothermal resources, $\mathrm{kJ}$.

$\mathrm{C}_{\mathrm{r}}, \mathrm{C}_{\mathrm{w}}$ - The specific heat of geothermal reservoir rocks and water, respectively, $\mathrm{kJ} / \mathrm{kg} \cdot{ }^{\circ} \mathrm{C}$.

$\rho_{\mathrm{r}}, \rho_{\mathrm{w}^{-}}$The density of geothermal reservoir rocks and water respectively, $\mathrm{kg} / \mathrm{m}^{3}$.

$\Phi$ - The porosity or fracture rate of geothermal reservoir rocks.

$\mathrm{q}_{\mathrm{w}}$ - The fluid reserves, including static reserves and elastic reserves, $\mathrm{m}^{3}$.

$\mathrm{T}_{1}$ - The temperature of the geothermal reservoir, ${ }^{\circ} \mathrm{C}$.

$\mathrm{T}_{0}$ - The temperature of the constant temperature zone, ${ }^{\circ} \mathrm{C}$.

$\mathrm{V}$ - The volume of the geothermal reservoir, $\mathrm{m}^{3}$.

According to the above-mentioned formula, it is obtained that the geothermal resource of Dunhuang Basin is $7.75 \mathrm{E}+16 \mathrm{~kJ}$. All the parameters and geothermal resource results are calculated (Table $\mathbf{1})$.

\section{CONCLUSION}

The geological structure, stratigraphic structure and the formation mechanism of geothermal water have been

Table 1. The geothermal reservoir parameters and the calculation results.

\begin{tabular}{|c|c|c|c|c|c|}
\hline $\begin{array}{l}\text { The Type } \\
\text { of Stratum }\end{array}$ & Area $\left(\mathbf{k m}^{2}\right)$ & $\begin{array}{l}\text { The Thickness } \\
\text { of Geothermal } \\
\text { Reservoir (m) }\end{array}$ & $\begin{array}{l}\text { The Volume of } \\
\text { the Geothermal } \\
\text { Reservoir }\left(\mathbf{m}^{3}\right)\end{array}$ & $\begin{array}{c}\text { The Porosity or } \\
\text { Fracture Rate of } \\
\text { Geothermal Reservoir } \\
\text { Rocks }\end{array}$ & $\begin{array}{l}\text { The Density of } \\
\text { Water }\left(\mathrm{kg} / \mathrm{m}^{3}\right)\end{array}$ \\
\hline $\begin{array}{l}\text { Conglomerate, } \\
\text { sandstone }\end{array}$ & 676.47 & 986 & $6.67 \mathrm{E}+11$ & 0.14 & 1000 \\
\hline $\begin{array}{l}\text { The temperature of the } \\
\text { geothermal reservoir } \\
\qquad\left({ }^{\circ} \mathrm{C}\right)\end{array}$ & $\begin{array}{l}\text { The temperature of the } \\
\text { constant temperature zone } \\
\left({ }^{\circ} \mathrm{C}\right)\end{array}$ & $\begin{array}{l}\text { The specific heat of } \\
\text { geothermal reservoir rocks } \\
\left(\mathrm{kJ} / \mathrm{kg} \cdot{ }^{\circ} \mathrm{C}\right)\end{array}$ & $\begin{array}{l}\text { The specific heat of water } \\
\qquad\left(\mathrm{kJ} / \mathrm{kg} \cdot{ }^{\circ} \mathrm{C}\right)\end{array}$ & $\begin{array}{l}\text { The density of geothermal } \\
\text { reservoir rocks }(\mathrm{kg} / \mathrm{m} 3)\end{array}$ & $\begin{array}{l}\text { The geothermal } \\
\text { resource }(\mathrm{kJ})\end{array}$ \\
\hline 57.6 & 12 & 0.8778 & 4.18 & 2600 & $7.75 E+16$ \\
\hline
\end{tabular}


analyzed based on the formation characteristics of the geothermal resources. The analysis result shows the geothermal reservoir parameters, including the area, thickness and temperature of the geothermal reservoir and porosity, etc. Based on the geothermal reservoir model, the conclusion was that the geothermal reservoir resource of Dunhuang Basin was $7.75 \mathrm{E}+16 \mathrm{~kJ}$. The results provides an advice for the exploitation of geothermal resources in sedimentary basins.

\section{CONFLICT OF INTEREST}

The authors confirm that this article content has no conflict of interest.

\section{ACKNOWLEDGEMENTS}

This study was funded by the National Natural Science Foundation of China (41302186).

\section{REFERENCES}

[1] Hu, S.B; Wang, J.Y. The basic principles and progress in the study of sedimentary thermal system. Earth Sci. Front., 1995, 4, 171-180.
[2] Qiu, N.S. The thermal condition section of sedimentary basins in Chinese mainland. Adv. Earth Sci., 1998, 13(5), 447-450.

[3] Shi, S.M; Zhu, H.L; Liang, Y.J. Establishment and application of sedimentary basin geothermal water resources quantitative evaluation system. J. Daqing Petrol. Inst., 2004, 5, 4-6.

[4] Khutorskoi, M.D; Polyak, B.G. Geothermal models of various geodymanic settings. Geotectonics, 2014, 48(1), 68-85.

[5] Dotsika, E; Poutoukis, D; Raco, B. Fluid geochemistry of the Methana Peninsula and Loutraki geothermal area, Greece. $J$ Geochem. Explor., 2010, 104(3), 97-104.

[6] Planer-Friedrich, B; London, J; McCleskey, R.B; Nordstrom D.K; Wallschläger D. Thioarsenates in geothermal waters of Yellowstone National Park: determination, preservation, and geochemical importance. Environ. Sci. Technol., 2007, 41(15), 5245-5251.

[7] Majumdar, N; Mukherjee, A.L; Majumdar, R.K. Mixing hydrology and chemical equilibria in Bakreswar geothermal area, Eastern India. J. Volcanol. Geotherm. Res., 2009, 183(3), 201-212.

[8] Saibi, H; Ehara, S. Temperature and chemical changes in the fluids of the Obama geothermal field (SW Japan) in response to field utilization. Geothermics, 2010, 39(3), 228-241.

[9] Vieira, F.P; Hamza, V.M; Alexandrino, C.H. Obliteration of thermal springs by groundwater flows in sedimentary basins of Brazil. Hydrogeol. J., 2014, 22(1), 69-86.

[10] Lin, W.J; Liu, Z.M; Wang, W.L. The assessment of geothermal resources potential of China. Geol. China, 2013, 40(1), 312-321.

(C) He et al.; Licensee Bentham Open

This is an open access article licensed under the terms of the Creative Commons Attribution Non-Commercial License (http://creativecommons.org/licenses/by-nc/4.0/) which permits unrestricted, non-commercial use, distribution and reproduction in any medium, provided the work is properly cited. 